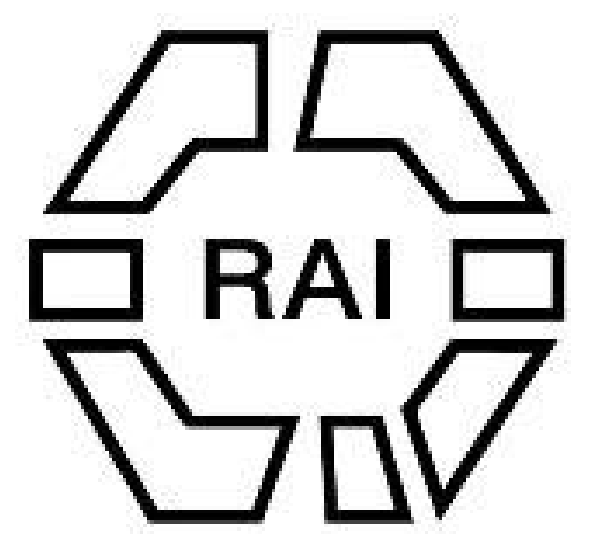

\title{
WILEY
}

\section{Death Customs in Burma}

\section{Author(s): R. Grant Brown}

Source: Man, Vol. 16 (Feb., 1916), pp. 22-23

Published by: Royal Anthropological Institute of Great Britain and Ireland Stable URL: http://www.jstor.org/stable/2787629

Accessed: 27-06-2016 09:54 UTC

Your use of the JSTOR archive indicates your acceptance of the Terms \& Conditions of Use, available at

http://about.jstor.org/terms

JSTOR is a not-for-profit service that helps scholars, researchers, and students discover, use, and build upon a wide range of content in a trusted digital archive. We use information technology and tools to increase productivity and facilitate new forms of scholarship. For more information about JSTOR, please contact support@jstor.org.

Royal Anthropological Institute of Great Britain and Ireland, Wiley are collaborating with JSTOR to digitize, preserve and extend access to Man 
(7) Another fragment of the same type, $15 \mathrm{~mm}$. thick, black outside and reddish inside; it has also the red flashes due to bad baking.

(8) A fragment of a vase $7 \mathrm{~cm}$. long and $20 \mathrm{~mm}$. thick, made of reddish clay having in it fragments of shells; on the surface of this sherd can be noticed curved lines very roughly incised, intended for ornament.

(9) Fragment of a roughly made vase having a buff slip on both sides, thickness 5 to $10 \mathrm{~mm}$.

(10) A handle of a large jar, poorly baked and of a very fine texture; it belongs to the transition period between the Neolithic and the Punic.

Besides these there is also a good number of sherds belonging to vessels of undoubted Punic type, and the bottom of a vase of red clay with fine black paint, undoubtedly of Greek manufacture.

THOMAS ASHBY. GIUSEPPE DESPOTT.

\section{Burma.}

Death Customs in Burma. By R. Grant Brown.
Mr. Perry's article on "The Orientation of the Dead in Indonesia," in 15

R. Grant Brown, the Journal for the second half of 1914, has suggested inquiry as to the treatment of the dead among the Burmese. The following notes are the result.

The corpse is invariably buried with its head to the east. In praying, a Burman Buddhist always turns to the east if there is no symbol of his religion in the neighbourhood, in spite of the fact that Gotama's country lies to the west of Burma. A Burman may sleep with his head to the east or south, never to the west or north. Solar myths are not particularly in evidence in Burma, and the people themselves do not connect the custom with the rising sun. It is possible that its origin may be, as suggested by Mr. Perry (following Herbert Spencer) the fact that the race migrated from the east, or in other words from China, where there are still tribes speaking languages closely allied to Burmese, and where such tribes were probably more numerous formerly than now. (The Tamans, for instance, undoubtedly came from China. See the Journal for the latter half of 1911.) But this does not explain the alternative allowed to the sleeper of lying with his head to the south, unless this is a Talaing custom, and the Talaings came by sea. More information is required regarding the customs of neighbouring races before any safe inference can be drawn.

In the funeral procession the corpse is always carried feet foremost. In Lower Burma great care is taken not to drop the coffin, or even to place it on the ground, on the way to the cemetery. If this happens it is believed that some one will die on that spot. When buried, the corpse must not face the village, but this prohibition also seems to be in force only in Lower Burma, and therefore to be of Talaing, rather than Burmese, origin.

The cemetery must be to the west or north of the village. This is merely the result of the idea that the east and south (south is the "honourable" quarter in China) are honourable and the west and north the reverse.

A corpse is never removed to a house before being buried. If a man dies outside his house, his body must not be placed in it, or even in the village, if he died outside the village.

In Upper Burma, drowned persons are buried near the water in which they were drowned, as far from it as a handful of water can be thrown; or, if the corpse is taken to a cemetery, water must be dropped along the path the whole way. It is believed that there will be a drought if this is not done.

In Lower Burma all the pots in the house are broken when the head of the household dies, but not when anyone else dies. Water is sprinkled on the place of 
death (this is done in Upper Burma also) immediately after removal of the body, and along the path from the house to the gate of the compound. As water frequently takes the place of blood in Buddhist ceremonies, both these customs may perhaps be regarded as a survival of the practice of killing slaves on the death of their master.

The Burmese appear to have no ideas regarding the direction of the land of the dead, or of the country from which the race came.

The curious device of holding a complete funeral and burial ceremony in the hope of deceiving the Destroyer, and inducing him to leave a sick person alone, was fully described in MAN, 1909, 13, under the heading "Cheating Death."

The Burman regards it as a matter of course that the soul should continue to exist after death, and he believes that it remains in the house, and is cognizant of all that goes on there, for seven days. The bed of the deceased person is laid, and a fresh supply of food and water is placed by it every morning and evening. During the same period hospitality is offered to all who come, and monks are invited to preach as well as to eat. At the end of the seven days the spirit departs. According to my principal informant, he is ejected by the house-god, Min Magayi, the mighty blacksmith who was burnt alive by a king of Tagaung, and whose spirit watches over every Burman household. But during the seven days he is not absolutely confined to the house. He may wander about visiting the places he was wont to visit in life.

In 1907 the Civil Surgeon of Pyapon died while I was Deputy Commissioner of the district. He was a native of Arakan. The day after bis death a messenger came to me from his widow asking me whether I would sign an order discharging. him from Government service. The reason given was that his ghost had been walking about the hospital and disturbing the patients there. Until he was removed or allowed to resign be was still under the orders of his superior officers, and considered it his duty to go on with his work. I objected that I had no power to remove a Civil Surgeon, but was told that my order would be quite effective for the purpose. Of course I consented; but I was somewhat startled a little later when an official letter was placed before me, addressed to the dead man and informing him that he was removed from Government service, with effect from an hour and date mentioned, these being the hour and date at which he died. I signed the letter, and was told afterwards that it had had the desired effect.

A creditor has a better chance of recovering a debt from the dead than from the living, provided the deceased has relations who are concerned for his welfare. If the debt is not paid it is believed that the dead man will come into the creditor's power, as his slave (nowadays servant), his ox, or his dog. R. GRANT BROWN.

\section{A further Note on the Use of the Wooden Trumpet in Papua. If}

In MAN, 1915, 11 (February), Dr. Seligman discusses the wooden trumpet as used on the southern slopes of the Hydrographers Range. A few remarks on the further distribution of this instrument may be of interest.

Dr. W. M. Strong, from whom Dr. Seligman obtained the specimen figured in MAN, states that he knows of the use of the wooden trumpet only in the region quoted, but I am able to point out from personal knowledge that its distribution is very much wider.

Naturally, the coast tribes use the ordinary conch shell as a trumpet, and the people of the hinterlands obtain their shell instruments from them in the way of trade; but the further one penetrates inland, the more difficult it becomes to obtain shells. I have found the wooden trumpet, almost identical with the instrument figured by Dr. Seligman, used over a large portion of the alministrative Northern 